Transport and Communications Science Journal, Vol. 71, Issue 7 (09/2020), 775-788

Transport and Communications Science Journal

\title{
EFFECT OF GROUND GRANULATED BLAST FUNRNACE SLAG AND FLY ASH ON STRENGTH, PERMEABILITY, AND UNDER- WATER ABRASION OF FINE-GRAINED CONCRETE
}

\author{
Truong Van Quyet*, Nguyen Thanh Sang
}

University of Transport and Communications, No 3 Cau Giay Street, Hanoi, Vietnam

ARTICLE INFO

TYPE: Research Article

Received: $18 / 8 / 2020$

Revised: $15 / 9 / 2020$

Accepted: 21/9/2020

Published online: 30/9/2020

https://doi.org/10.47869/tcsj.71.7.4

* Corresponding author

Email: quyet.tv@utc.edu.vn; Tel: 0978452140

Abstract. The utilisation of supplementary cementitious materials (SCMs) is widespread in the concrete industry because of the performance benefits and economic. Ground granulated blast furnace slag (GGBFS) and fly ash (FA) have been used as the SCMs in concrete for reducing the weight of cement and improving durability properties. In this study, GGBFS at different cement replacement ratios of $0 \%, 20 \%, 40 \%$ and $60 \%$ by weight were used in finegrained concrete. The ternary binders containing GGBFS and FA at cement replacement ratio of $60 \%$ by weight have also evaluated. Flexural and compressive strength test, rapid chloride permeability test and under-water abrasion test were performed. Experimental results show that the increase in concrete strength with GGBFS contents from $20 \%$ to $40 \%$ but at a higher period of maturity (56 days and more). The chloride permeability the under-water abrasion reduced with the increasing cement replacement by GGBFS or a combination of GGBFS and FA.

Keywords: fine-grained concrete, supplementary cementitious materials (SCMs), GGBFS, fly ash, rapid chloride permeability, abrasion underwater.

(C) 2020 University of Transport and Communications

\section{INTRODUCTION}

Concrete is so common material that is widely used in construction such as bridges, pavements, airfield runways, dams. etc. However, the cement and concrete industries are estimated to account for about $6 \%-8 \%$ of global man-made $\mathrm{CO}_{2}$ emissions [1]. Currently, the development trend of creating concrete with less impact on the environment is increasingly 
concerned.

There are many ways to improve the sustainability of concrete [2] such as replacing the portland cement with supplementary cementing materials (SCMs), using higher strength concretes, using recycled concrete, etc. SCMs are used to replace a part of cement in concrete. SCMs can be fly ash, ground granulated blast furnace slag, silica fume, and metakaolin. Currently, the world's problems with energy use, emissions, waste treatment, and depletion of natural resources are increasing considerably. Concrete containing SCMs that partially replace cement has been widely used for decades and is considered as a sustainable material in construction [3]. The presence of SCM leads to a change of hydration products, resulting in a change in volume, porosity, and eventually the mechanical and durability properties of concrete [3,4]. The hydration reaction of cement and mineral admixture can occur simultaneously and interact with each other, or it is assumed that the hydration reaction of cement takes place before that of SCM [4]. The properties, such as chemical composition, fineness, the concentration of the active phase, will determine the SCM activity. The chemical effect is created by the pozzolanic reaction between SCM's amorphous silica with $\mathrm{Ca}(\mathrm{OH})_{2}$ generated by cement hydration [5, 6], and/or by the hydraulic reaction of SCM itself, such GGBFS [7, 8]. In addition, the partial replacement of cement by SCM filling the voids between cement particles would increase the packing density, then the strength and durability of concrete [3, 8-10].

Blast furnace slag is a by-product of iron and steel production. Ground granulated blast furnace slag is a blast furnace slag that is ground to an appropriate fineness and is a selfhydrating material similar to cement. The utilization of blast furnace slag in cement production has contributed to the treatment of industrial waste sources. Due to higher $\mathrm{C} / \mathrm{S}$ ratio than the other pozzolans, GGBFS may be regarded as a latently hydraulic instead of pozzolanic, it reacts with water [4], chemically hardens. The application of GGBFS in the production of the concrete has been gaining attention [11-16]. GGBFS can be used to replace as much as $80 \%$ of the cement in concrete [17]. Fly ash (FA) is a by-product of coal combustion. This is the most widely used SCM and is added to concrete to replace from 15 to $35 \%$ of cement by weight to achieve optimum performance. In massive structures, report suggest that higher levels of fly ash should be used (up to 60\%) to help control the thermal cracking [18]. Like most pozzolanic materials, fly ash slows down the development of concrete strength at an early age, but concrete will gain strength and durability at later ages. Researches have shown that using fly ash in concrete improves the strength and durability properties of concrete [19]. The benefits of concrete using fly ash in the fresh and solid-state, along with sustainability, allow the research to be carried out with fly ash content replacing more than $50 \%$ by weight [20]. Moreover, the related researches on the combined effect of FA and GGBFS as replacement of cement on both fresh and hardened concrete of concrete were also analyzed [14, 21-23].

Fine-grained concrete is considered as a new generation of sand concrete including aggregate passing through $4.75 \mathrm{~mm}$ sieve, cement, SCMs, water, and superplasticizer. The objective of this study is to investigate the effect of GGBFS and FA on properties of finegrained concrete. Fresh characteristic, flexural and compressive strength, rapid chloride permeability_(RCP) and under-water abrasion were evaluated. In this study, GGBFS at different cement replacement ratios of $0 \%, 20 \%, 40 \%$ and $60 \%$ by weight were used in finegrained concrete. The ternary binders containing GGBFS and FA at cement replacement ratio of $60 \%$ by weight have also evaluated. These results can be considered for the design of 
Transport and Communications Science Journal, Vol. 71, Issue 7 (09/2020), 775-788

reinforced concrete structures in marine conditions.

\section{EXPERIMENTAL PROGRAM}

\subsection{Materials}

Cement PC40 VICEM But Son was used and standard tests were conducted according to TCVN 2682-2009. The specific gravity of cement is $3.1 \mathrm{~g} / \mathrm{cm}^{3}$. GGBFS was collected from Hoa Phat Steel with specific gravity of $2.9 \mathrm{~g} / \mathrm{cm}^{3}$. Class $\mathrm{F}$ fly ash was used according to ATSM C618 [24]. It was collected from Vung Ang Power House, Ha Tinh. The specific gravity of fly ash is $2.4 \mathrm{~g} / \mathrm{cm}^{3}$. The chemical composition of GGBFS, fly ash and cement showed in Table 1. Crushed sand passing through sieve is $4.75 \mathrm{~mm}$ and the fineness modulus is 3.4. Fine sand was collected from Cam Xuyen, Ha Tinh. Fine sand passing through sieve is $1.18 \mathrm{~mm}$ and the fineness modulus is 1.5. Specific gravities of fine sand and crushed sand are $2.65 \mathrm{~g} / \mathrm{cm}^{3}$ and $2.68 \mathrm{~g} / \mathrm{cm}^{3}$, respectively. The particle distribution of sand was tested according to ASTM C136 [25], as shown in Figure 1. The test results of characteristics of fine sand are shown in Table 2. This research used Master Glenium ACE 8509 as a chemical admixture.

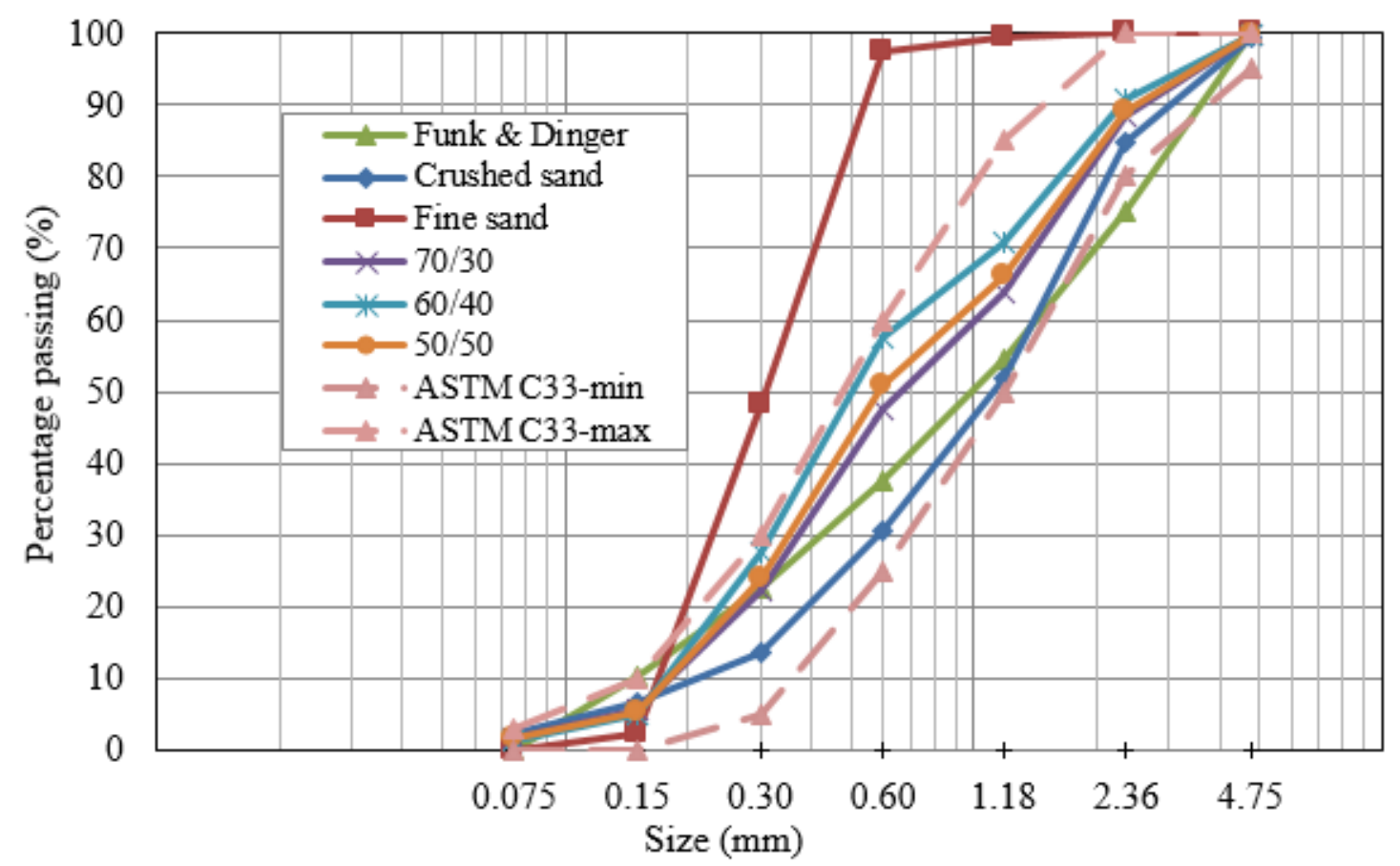

Figure 1. Particle distribution curves of coarse/fine sand in different ratios.

Table 1. Chemical composition of GGBFS, fly ash and cement.

\begin{tabular}{cccccccccc}
\hline \hline & $\mathrm{CaO}$ & $\mathrm{SiO}_{2}$ & $\mathrm{Fe}_{2} \mathrm{O}_{3}$ & $\mathrm{Al}_{2} \mathrm{O}_{3}$ & $\mathrm{MgO}$ & $\mathrm{K}_{2} \mathrm{O}$ & $\mathrm{Na}_{2} \mathrm{O}$ & $\mathrm{SO}_{3}$ & $\begin{array}{c}\text { Mean particle } \\
\text { size }(\boldsymbol{\mu m})\end{array}$ \\
\hline GGBFS & 34.7 & 36.6 & 0.03 & 12.91 & 7.78 & 1.26 & 0.52 & 1.45 & 12.20 \\
\hline Fly ash & 4.27 & 53.9 & 6.7 & 21.8 & 1.45 & 3.4 & 0.67 & 0.2 & 26.87 \\
\hline Cement & 63.2 & 21.9 & 3.3 & 5.72 & 1.1 & 0.3 & 0.12 & 1.9 & 16.12 \\
\hline \hline
\end{tabular}


Transport and Communications Science Journal, Vol. 71, Issue 7 (09/2020), 775-788

Table 2. Test result of characteristics of fine sand.

\begin{tabular}{cccc}
\hline Characteristics & Result & Test method \\
\hline Quantity Sc - Dissolved silica, mMol/1 & 18 & \\
\cline { 1 - 2 } Quantity - Reduction in Alkalinity, mMol/1 & 38 & ASTM C289-2007 & \\
\hline Chloride content, ppm & & TCVN 141-2008 \\
\hline Sulfate content, ppm & $<10$ & \\
\hline \hline
\end{tabular}

\subsection{Mix proportion}

Theoretically, there exists a grading of the aggregate with maximum particle size will produce the maximum density. This grading would involve a particle arrangement where smaller particles are packed within the porosity between larger particles. Then, the void ratio between particles is a minimum (corresponding to maximum density). Practically, the grading with maximum density is not desired because a void content in the compacted aggregate is required for the paste volume [26]. Funk and Dinger [27] developed a theory about the density of aggregate blend that has the equation:

$$
P(D)=\frac{D^{q}-D_{\min }^{q}}{D_{\max }^{q}-D_{\min }^{q}}
$$

Where, $P(D)$ is percent passing $D \mathrm{~mm}, \mathrm{D}_{\min }$ and $\mathrm{D}_{\max }$ are the minimum and maximum particle sizes in the aggregate blend, $\mathrm{mm}$.

In this research, Funk and Dinger theory is applied with exponent $q=0.25, D_{\max }=4.75$ $\mathrm{mm}$ and $\mathrm{D}_{\min }=0.075 \mathrm{~mm}$. The lines show the particle distribution of the aggregate blend with different crushed/fine sand ratios (as shown in Figure 1). Experimental results have been indicated that the 60/40 ratio of crushed/fine sand created an aggregate blend which suitable with theoretical curves and reach the flow requirement. Therefore, the crushed/fine ratio of $60 / 40$ has been selected for the mixture design procedure of fine-grained concrete.

The flow of fine-grained concrete mixtures was measured by a non-standard method. The flow $(\mathrm{mm})$ of fine-grained concrete mixtures was determined by using a mini cone with a large bottom diameter of $100 \mathrm{~mm} \pm 0.5 \mathrm{~mm}$, a small bottom diameter of $70 \mathrm{~mm} \pm 0.5 \mathrm{~mm}$, and a height of $60 \mathrm{~mm} \pm 0.5 \mathrm{~mm}$. It was determined by measuring the average of the two diameters perpendicular to each other (Figure 2).

In this study, the fine-grained concrete mixtures were held at a uniform flow from 250 to $280 \mathrm{~mm}$ using various dosages of superplasticizer. Experimental results show that to achieve workability requirements, the superplasticizer dosage for $100 \% \mathrm{PC}$ concrete mixture is $1.4 \%$. For concrete mixtures using GGBFS or using a combination of GGBFS and FA, the superplasticizer dosage is $1.2 \%$. 

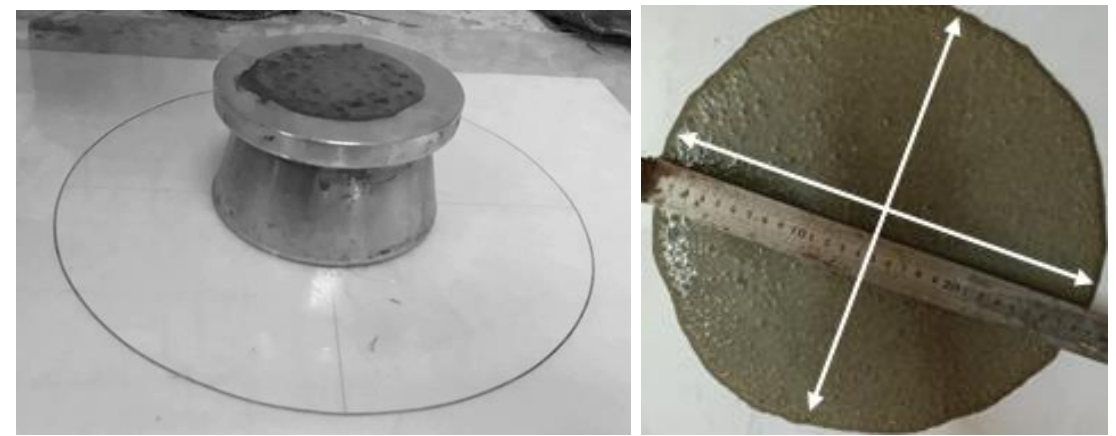

Figure 2. The flow test of fine-grained concrete mixture.

The mixture proportions of fine-grained concrete were determined by the theory of absolute volume. The requirement of fine-grained concrete mixture has the flow from 250 to $280 \mathrm{~mm}$ and the concrete has a compressive strength of $50 \mathrm{MPa}$. The ratio of water/binder (w/b) was determined on the basis of compressive strength. GGBFS was used to replace cement with $0 \%, 20 \%, 40 \%$ and $60 \%$ by weight. The binders containing GGBFS and FA were also used to replace with $60 \%$ by weight. Six types of concretes are presented in Table 3 .

Table 3. Mixture proportions of fine-grained concrete.

\begin{tabular}{lcccccc}
\hline \hline & $\mathbf{1 0 0 \%} \mathbf{P C}$ & $\begin{array}{c}\mathbf{2 0 \%} \\
\text { GGBFS }\end{array}$ & $\begin{array}{c}\mathbf{4 0 \%} \\
\text { GGBFS }\end{array}$ & $\begin{array}{c}\text { 60\% } \\
\text { GGBFS }\end{array}$ & $\begin{array}{c}\text { 20\%FA40\% } \\
\text { GGBFS }\end{array}$ & $\begin{array}{c}\text { 30\%FA30\% } \\
\text { GGBFS }\end{array}$ \\
\hline Cement, kg & 612 & 487 & 363 & 240 & 238 & 238 \\
\hline GGBFS, kg & 0 & 122 & 242 & 360 & 238 & 178 \\
\hline Fly ash, kg & 0 & 0 & 0 & 0 & 119 & 178 \\
\hline Crushed sand, kg & 891 & 891 & 891 & 891 & 891 & 891 \\
\hline Fine sand, kg & 594 & 594 & 594 & 594 & 594 & 594 \\
\hline Water, kg & 226 & 225 & 224 & 222 & 220 & 219 \\
\hline Superplasticizer, kg & 8.3 & 7.1 & 7.0 & 7.0 & 6.9 & 6.9 \\
\hline w/b ratio & 0.37 & 0.37 & 0.37 & 0.37 & 0.37 & 0.37 \\
\hline Flow (mm) & $260 \pm 5$ & $260 \pm 5$ & $270 \pm 5$ & $275 \pm 5$ & $280 \pm 5$ & $280 \pm 5$ \\
\hline
\end{tabular}

\subsection{Preparations of test specimens}

Proceed to cast specimens with dimensions of $40 \times 40 \times 160 \mathrm{~mm}$, a group includes 3 specimens. After being cast, specimens should be kept in a dry, ventilated place for 24 hours after casting, remove the mold, type symbols and immersion in water. The flexural strength and compressive strength was tested according to TCVN 6016-2011 at the age of 3, 7, 28, 56 and 120 days (as shown in Figure 3). 


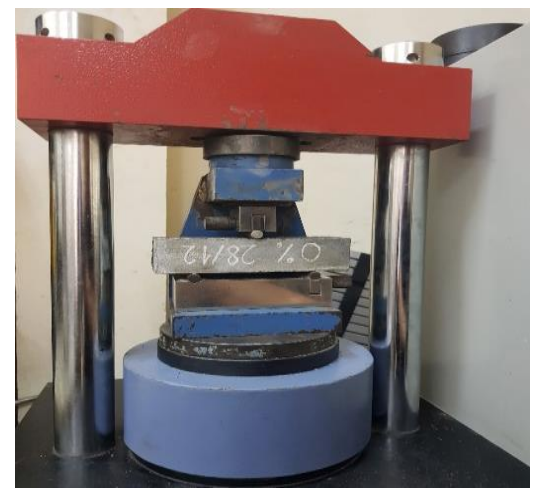

(a) flexural strength test.

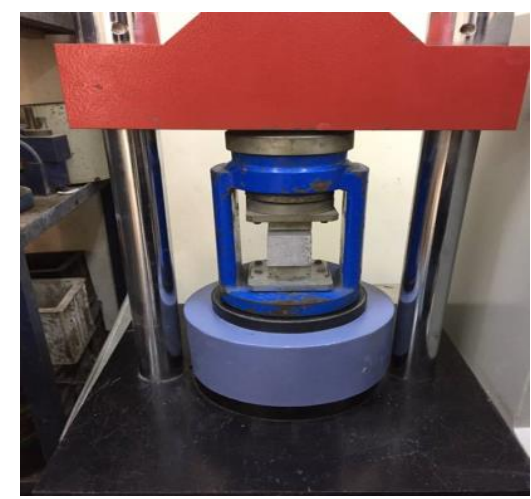

(b) compressive strength test.

Figure 3. Flexural and compressive strength test.

Chloride ion permeability was determined according to ASTM C1202, also called Rapid Chloride Permeability Test (RCPT) [28] (as shown in Figure 4). In the RCPT, specimens were placed between two acrylic cells. One of the cells was filled with a 0.3 mole/ $\mathrm{L} \mathrm{NaOH}$ solution and the other cell was filled with a $3 \% \mathrm{NaCl}$ solution. The cells were connected to a $60-\mathrm{V}$ power source. The current was measured and recorded for 6 hours and then the total charge passed through the specimen was computed by integrating the current over time (RCP). The curing period of concrete specimens was 28 days and 56 days in a water-curing tank placed in a temperature room. The specimens of size $50 \mathrm{~mm} \times 100 \mathrm{~mm}$ (height $\times$ diameter) were sealed with two epoxy resin coats in order to ensure one-dimensional chloride flow through the specimens. Specimens were saturated by placing in a vacuum container by ensuring that two end surfaces were exposed. The pressure was decreased less than $1 \mathrm{mmHg}$ and the vacuum was kept for four hours. Then, the specimens were immersed in water for $18 \pm 2$ hours before the test.

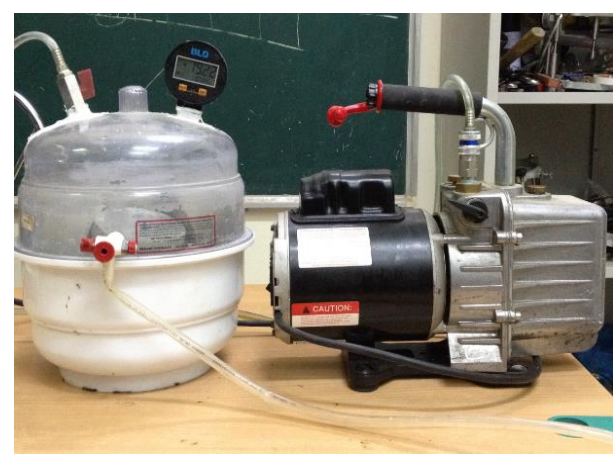

(a) vacuum container

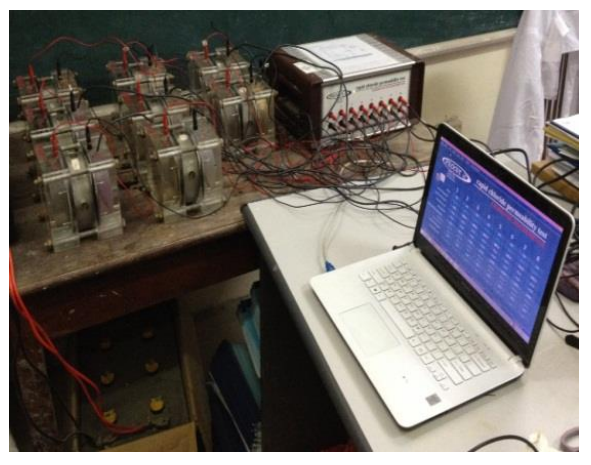

(b) test setup

Figure 4. Rapid chloride permeability test.

The under-water abrasion test was determined according to ASTM C1138 [29]. The test apparatus is shown in Figure 5b. A steel pipe with a chuck capable of holding and rotating the agitation paddle with steel balls under test conditions at a speed of $1200 \pm 100 \mathrm{rpm}$ is used. The test specimens of a diameter of $300 \pm 6 \mathrm{~mm}$ and a height of $40 \pm 2 \mathrm{~mm}$ were placed in the test container (Figure 5a). The test specimens are weighed at the 12 hours intervals during the 48 hours test period. Then, the volume of concrete lost at the end of each cycle was calculated. 


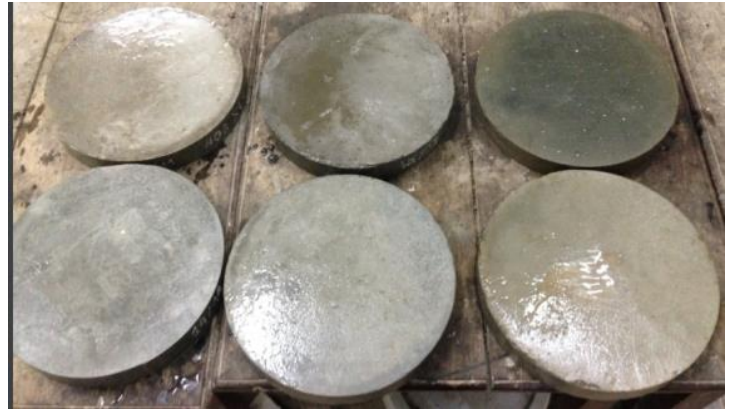

(a) Test specimens.

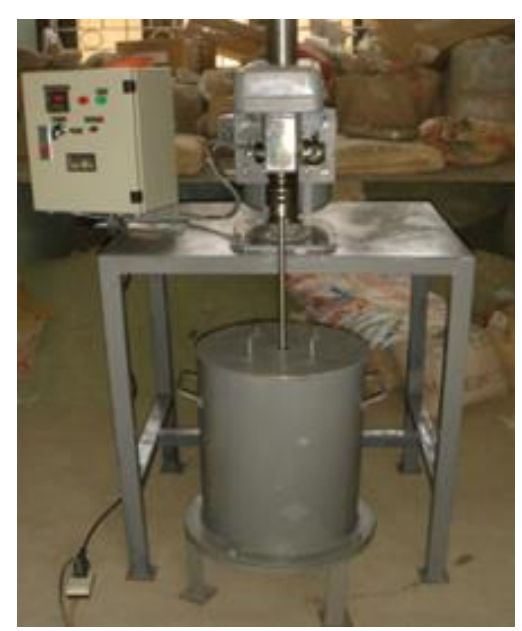

(b) Test apparatus.

Figure 5. Under-water abrasion test.

\section{RESULTS AND DISCUSSION}

\subsection{Fresh characteristic}

In this study, fresh characteristic of mixtures was assessed through the flow by a nonstandard method. The flow of the mixtures was measured immediated upton completion of mixing. The test results are presented in Table 3 (as also shown in Figure 6). It can be seen that, a flow from $250 \mathrm{~mm}$ to $280 \mathrm{~mm}$ was kept for mixtures by using an appropriate dosage of superplaticizer. To achieve uniform consistency of mixtures, using GGFS and FA lead to a reduction in the required dosage of superplaticizer. This is explained by the smooth surface texture and the delay in the chemical reaction of GGBFS and FA. Other study have also assumed that concrete using GGBFS requires less water than ordinary concrete [30].
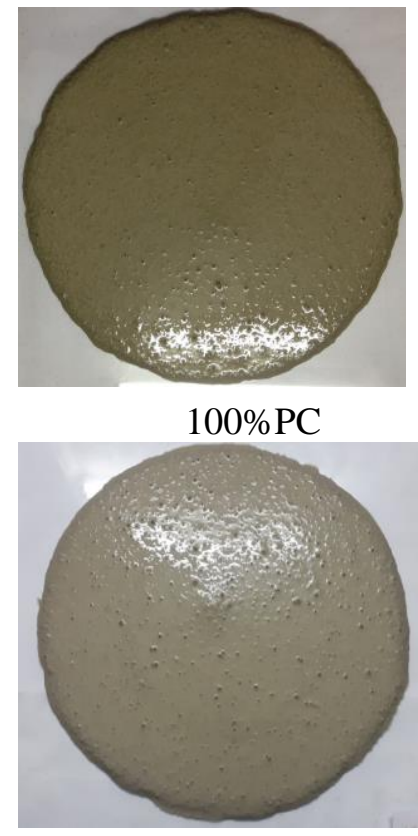

$60 \%$ GGBFS

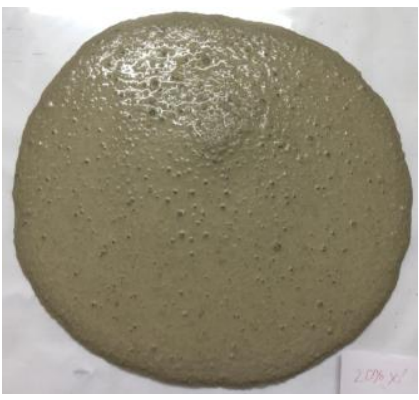

$20 \%$ GGBFS

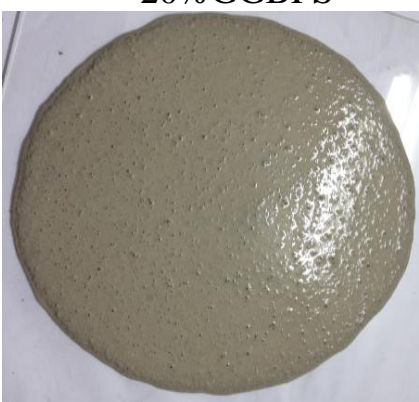

20\%FA40\%GGBFS

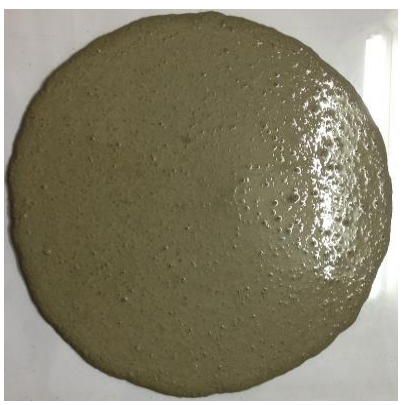

$40 \%$ GGBFS

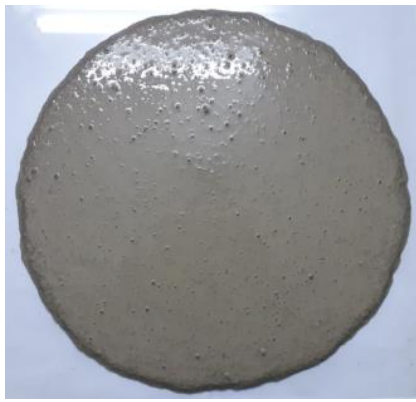

$30 \%$ FA30\%GGBFS

Figure 6. The flow of fine-grained concrete mixture. 


\subsection{Flexural and compressive strength}

Experimental results of flexural and compressive strength of concretes at 3, 7, 28, 56 and 120 curing days are shown in Figure 7 and Figure 8. Based on Figure 7, the flexural strength of concretes increases with time. At the early age of 3 and 7 days, flexural strength tends to decrease when increasing content of GGBFS or fly ash as replacement for cement, in contrast, at the late age, it tends to increase. The flexural strength of $100 \% \mathrm{PC}$ and $30 \% \mathrm{FA} 30 \% \mathrm{GGBFS}$ are $11.3 \mathrm{MPa}$ and $7.0 \mathrm{MPa}$, respectively.

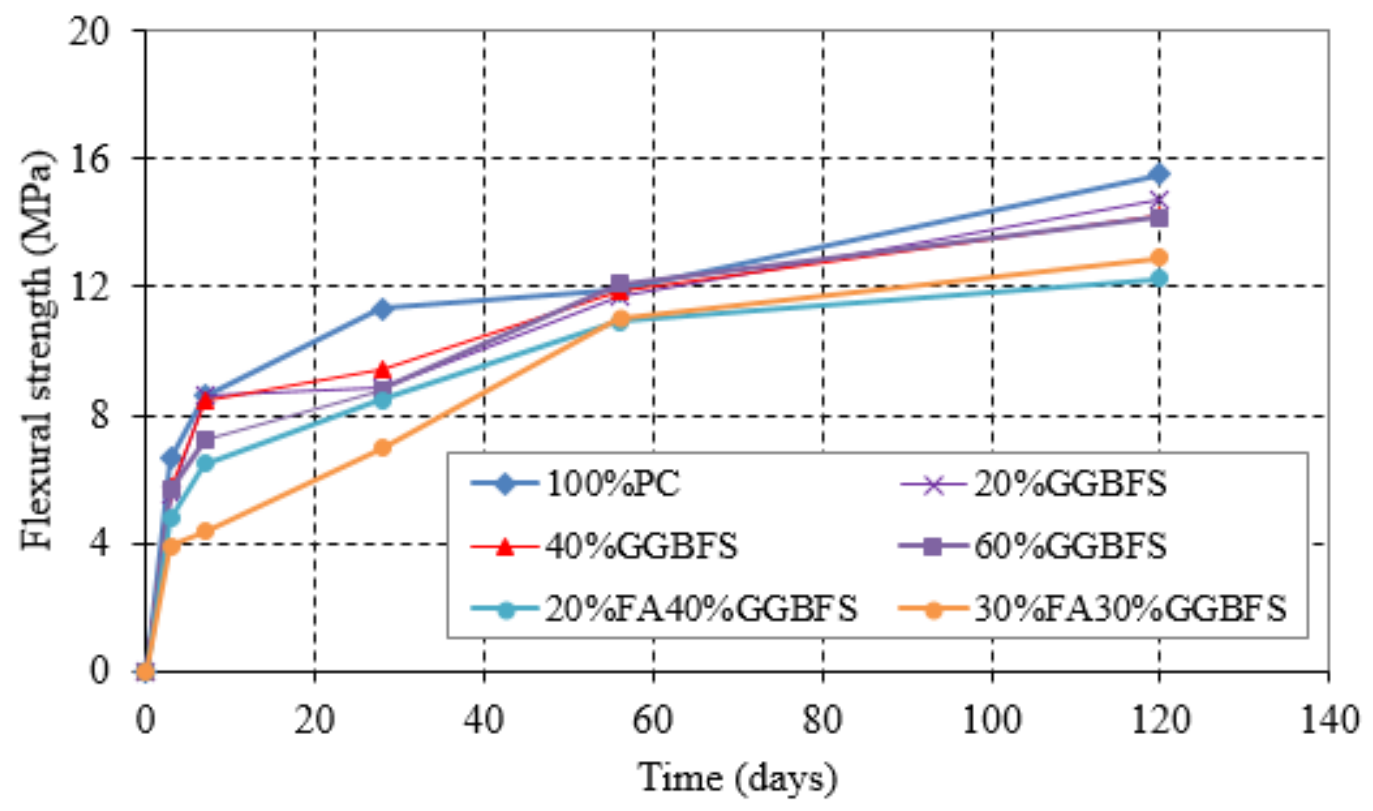

Figure 7. The development of flexural strength of concrete over time.

Similar to flexural strength, the compressive strength of concretes increases with time. The highest compressive strength at the age of 3 days is $42.0 \mathrm{MPa}$ with $100 \% \mathrm{PC}$ concrete and the lowest is $19 \mathrm{MPa}$ with $30 \% \mathrm{FA} 30 \% \mathrm{GGBFS}$ concrete. At the age of 28 days, the highest compressive strength is $56.3 \mathrm{MPa}$ with $100 \% \mathrm{PC}$ concrete and the lowest is $40.3 \mathrm{MPa}$ with $30 \%$ FA30\%GGBFS concrete. With 60\%GGBFS concrete, the compressive strength is 47.1 $\mathrm{MPa}$. However, at the later ages of 56 days and 120 days, the trend of compressive strength of concretes using GGBFS or a combination of GGBFS and fly ash is upward and equivalent with $100 \%$ PC concrete. The rate of strength development is faster than that of $100 \%$ PC concrete. At the age of 120 days, the highest compressive strength of $20 \%$ GGBFS concrete is 66.0 MPa.

The effect of GGBFS on compressive strength of fine-grained concrete is also shown in Figure 9. At the age of 3, 7 days, the presence of GGBFS reduces the strength of concrete because the hydratation of GGBFS is slower than cement at early ages, and the rate of reduction depends on the amount of GGBFS. The compressive strength at the age of 3 days decreased from 42.0 MPa to 27.5 MPa when GGBFS content increased from 0 to $60 \%$. So, with the increase of GGBS content, the compressive strength of concretes decreases at initial stage due to the reduction of hydration product of cement. At the later age of 56 days, the 
Transport and Communications Science Journal, Vol. 71, Issue 7 (09/2020), 775-788

compressive strength of concrete using GGBFS with content from 20 to $40 \%$ tends to be close to that of $100 \% \mathrm{PC}$ concrete. At the age of 120 days, the compressive strength of $20 \% \mathrm{GGBFS}$ concrete is higher than that of the control concrete. This is explained by the pozzolanic reactions occurred between the hydratation products $\left(\mathrm{Ca}(\mathrm{OH})_{2}, \mathrm{NaOH}, \mathrm{KOH}\right)$ of cement with the $\mathrm{SiO}_{2}$ provided by GGBFS at later ages [31]. This reaction prevails at long term and late age and thus to full fill the large pores as well as micropores within the cristalline phase by the pozollanic products. The hydration products which improves the pore structure and the interfacial transition zone, thus this significantly improves the compressive strength at later ages. Hence, GGBFS concrete with from $20 \%$ to $40 \%$ cement replacement can be the optimum replacement in this study.

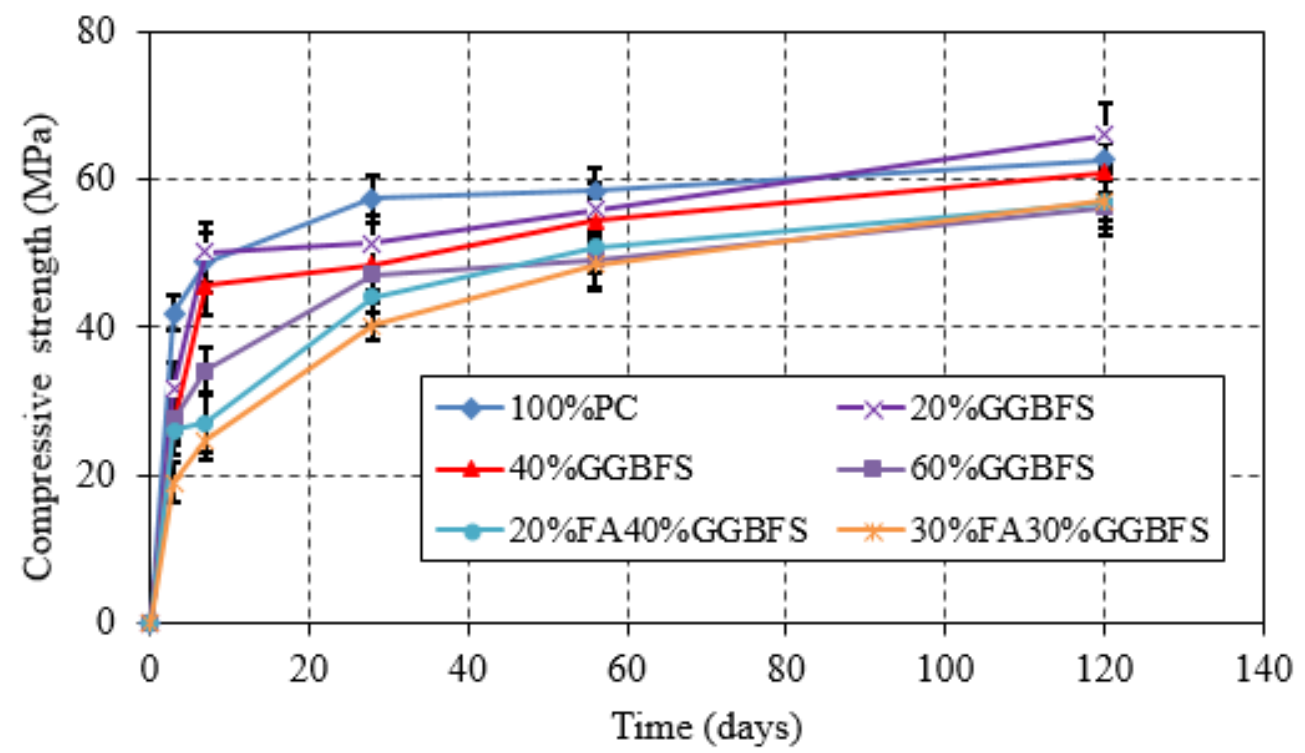

Figure 8. The development of compressive strength of concrete over time.

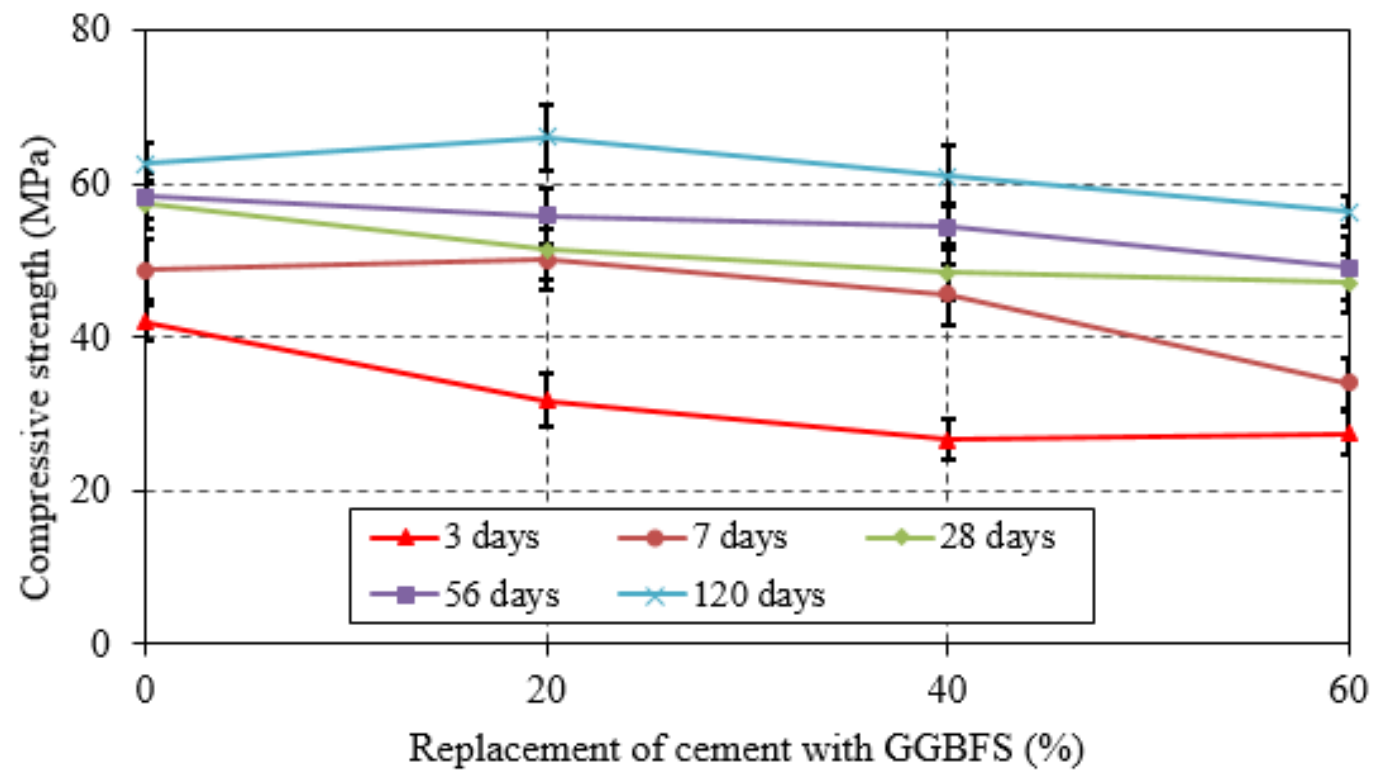

Figure 9. Effect of GGBFS on compressive strength. 
The effect of the combination of GGBFS and FA on the strength of fine-grained concrete is also shown in Figure 10. Three types of concrete with 60\%GGBFS, 20\%FA40\%GGBFS and 30\%FA30\%GGBFS were evalued. The results indicated that the use of fly ash reduced the strength of concrete at early 3 and 7 days. This is explained by the low hydraulic activity of fly ash during this time. At the age of 56 days, the compressive strength of $60 \% \mathrm{GGBFS}$ concrete, 20\%FA40\%GGBFS concrete and 30\%FA30\%GGBFS concrete are $49.1 \mathrm{MPa}, 50.9$ $\mathrm{MPa}$ and $48.5 \mathrm{MPa}$, respectively. The development of compressive strength of concrete using fly ash can be explained by the strong pozzolanic effect at this time [32].

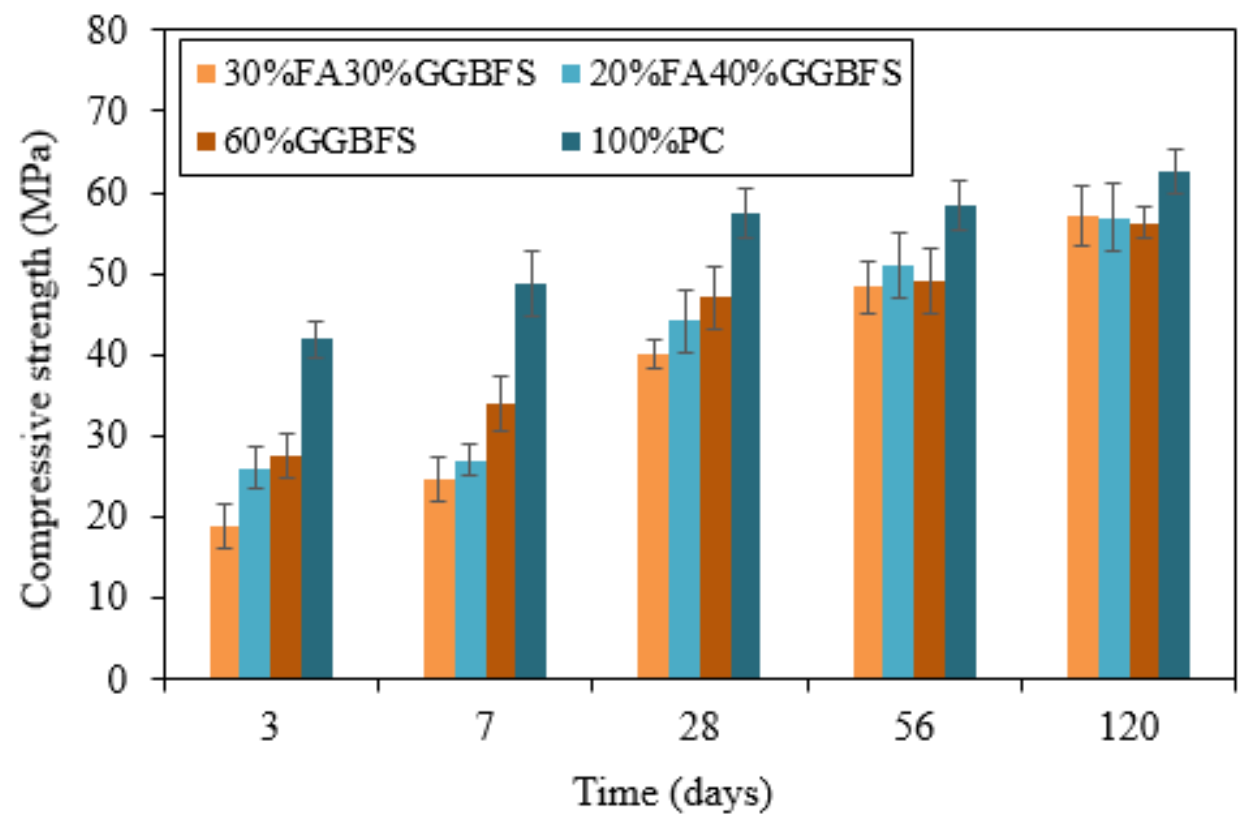

Figure 10. The effect of the combination of GGBFS and fly ash on the compressive strength.

\subsection{Chloride penetration resistance}

For this study, rapid chloride permeability test was used to evaluate concrete permeability. The test results of concretes at 28 days and 56 days are shown in Figures 11. For $100 \%$ PC concrete, the chloride ion penetration according to the rapid permeability test is "moderate" level at both 28 days and 56 days. At the age of 28 days, when using GGBFS to replace cement from 20 to $60 \%$, chloride ion penetration is "low" level. When replacing cement with GGBFS and FA (20\%FA40\%GGBFS and 30\% FA30\%GGBFS), chloride ion is "very low" level. At the age of 56 days, the chloride ion penetration is "very low" for concretes using GGBFS to replace cement from 40 to $60 \%$ or with concrete using a combination of GGBFS and fly ash.

From the experimental results, it can be seen that the presence of GGBFS and FA reduce chloride penetration in concrete. The appearance of large pores and crystalline products in concrete has been significantly reduced in concrete using mineral admixture. For fly ash concrete, due to the slow reaction of the hydration, crystalli ne products and intermittent pores are formed and thus reducing the chloride ion penetration in concrete at a later age compared to early age (Figure 11). 
Transport and Communications Science Journal, Vol. 71, Issue 7 (09/2020), 775-788

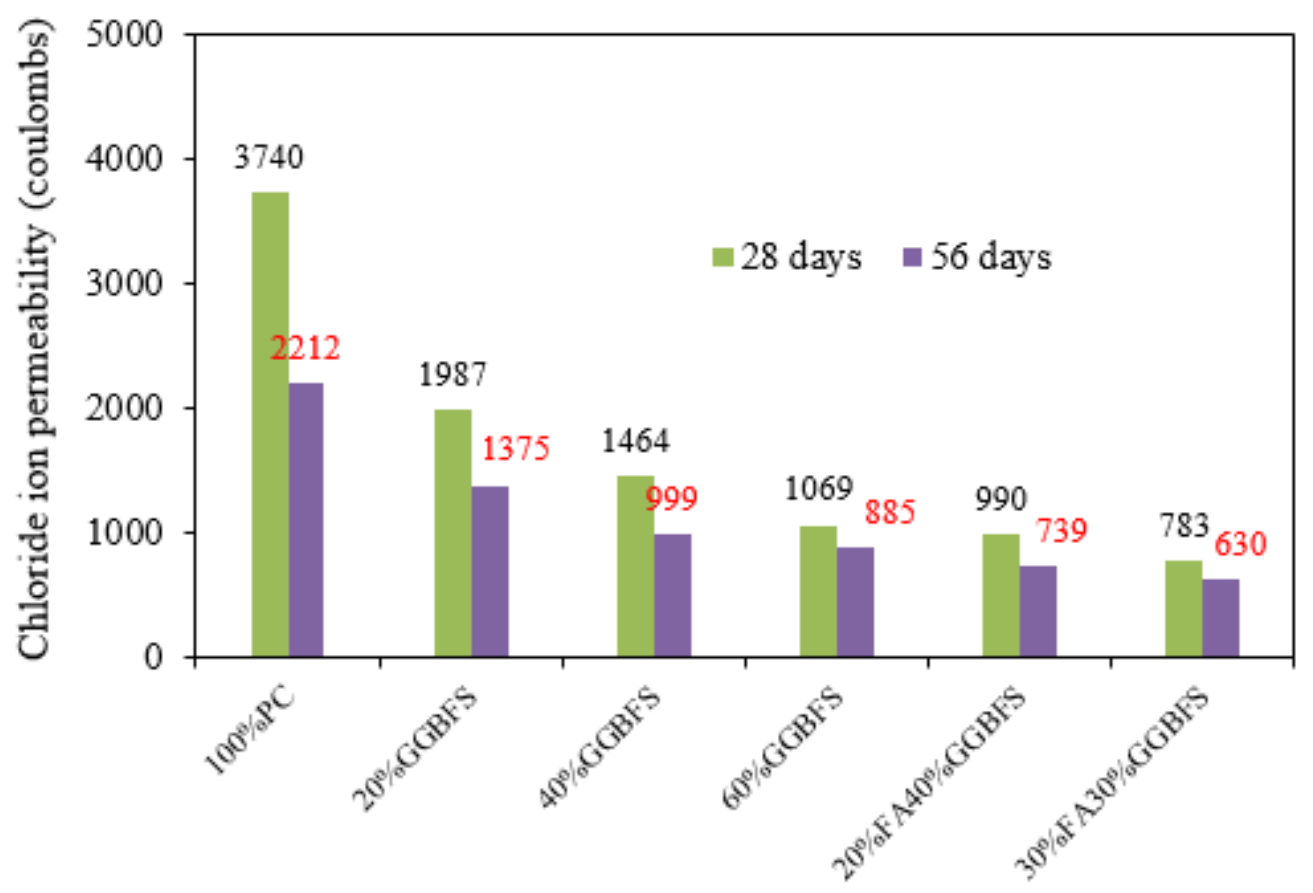

Figure 11. The effect of time on the chloride ion penetration of concretes.

\subsection{Under-water abrasion resistance}

Figure 12 shows that the abrasion volume increases when increasing test time for concretes at the age of 90 days. However, the level of abrasion under-water of concretes is different. In the 48 hours abrasion cycle, the abrasion of $100 \%$ PC concrete is the largest, $44.6 \mathrm{~cm}^{3}$ and decrease trend.

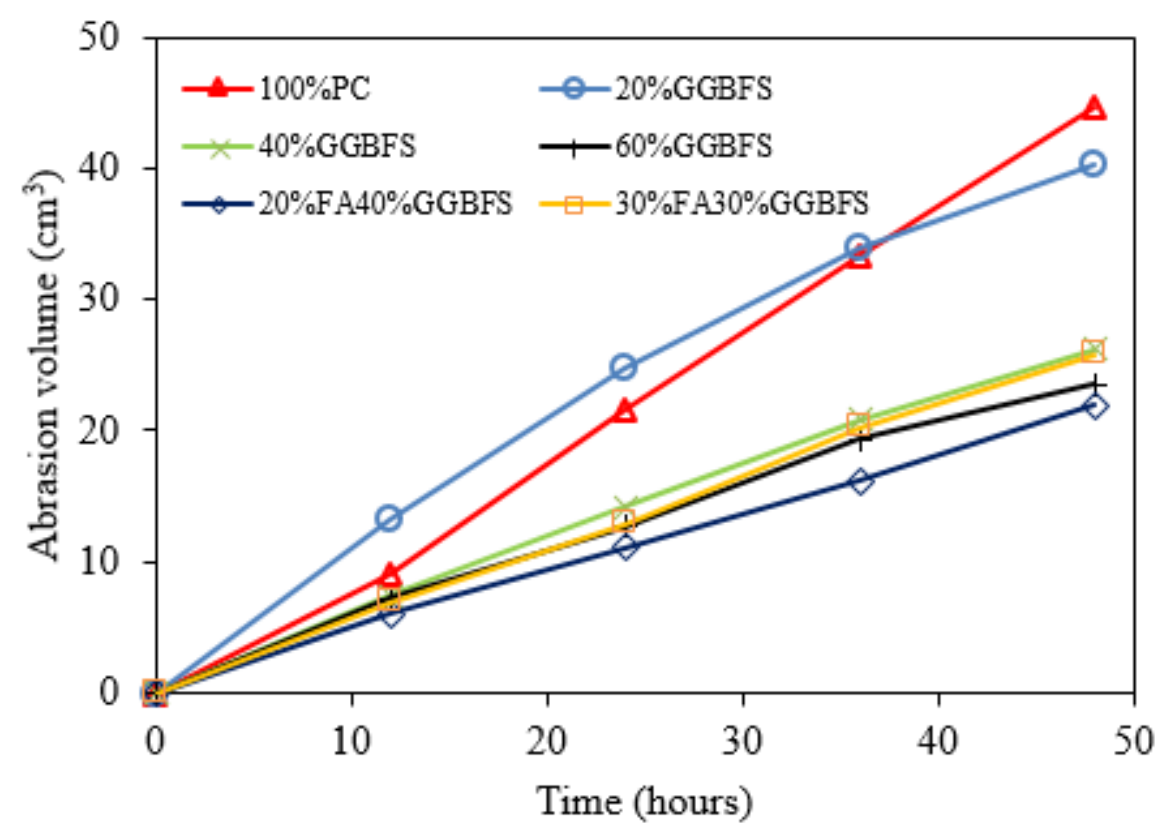

Figure 12. Abrasion volume of concrete specimens. 
When replacing cement with GGBFS with different contents, the results show that the abrasion volume of concrete using GGBFS is lower than concrete using only cement. The abrasion decreases with increasing content of GGBFS. The abrasion volume of the $60 \%$ GGBFS concrete is $23.5 \mathrm{~cm}^{3}$. For concrete using GGBFS combined fly ash (20\%FA40\%GGBFS and 30\%FA30\%GGBFS), the abrasion volumes are equivalent to concrete samples using GGBFS (60\% GGBFS), $21.9 \mathrm{~cm}^{3}$ and $25.8 \mathrm{~cm}^{3}$ respectively. Due to the strong pozzolanic properties of the GGBFS and FA at the later ages, the replacement of cement with the GGBFS and FA enables obtaining of the concrete with improved abrasion resistance. Based on the experimental results, it can be concluded that using GGBFS (or a combination of GGBFS and fly ash) can improve the under-water abrasion resistance of concrete.

\section{CONCLUSION}

Based on the above results and discussions, the following conclusions can be drawn:

1. The presence of GGBFS and FA can improve the consistency of fine-grained concrete mixtures.

2. The flexural and compressive strength of concretes increases with curing time. Test results show that GGBFS concrete with $20 \%$ to $40 \%$ cement replacement can be the optimum replacement in this study.

3. The experimental result shows that the abrasion under water of concrete using GGBFS are lower than that of $100 \% \mathrm{PC}$ concrete. The abrasion volume decreases with increasing content of GGBFS. For concrete using fly ash combined with GGBFS, the abrasion volume are equivalent to concrete using GGBFS. Therefore, using GGBFS (or a combination of GGBFS and FA) can improve the abrasion resistance of concrete.

4. Concrete using GGBFS and FA reduces chloride ion penetration compared to $100 \%$ PC concrete. In this research, the chloride ion penetration decrease when increasing the content of GGBFS and at the later ages.

\section{ACKNOWLEDGMENT}

This research is funded by University of Transport and Communications (UTC) under grant number T2020-XD-003. This research is also partly supported by the Project of Vietnam Ministry of Science and Technology, "Study on using saline sand to build transport work" under grant number DTDL.CN-23/19.

\section{REFERENCES}

[1]. S. Mindess, Developments in the Formulation and Reinforcement of Concrete (Sustainability of concrete), Second Edition, Woodhead Publishing Series in Civil and Structural Engineering, Elsevier Science \& Technology, 2019, pp. 9-24.

[2]. P.C. Aitcin, S., Mindess, Sustainability of concrete, Spon Press, Oxford, United Kingdom, 2011, pp. 301.

[3]. B. Lothenbach, K. Scrivener, R.D. Hooton, Supplementary cementitious materials, Cement and Concrete Research, 41 (2011) 1244-1256. https://doi.org/10.1016/j.cemconres.2010.12.001 
[4]. M. M. C. Canut, Pore structure in blended cement pastes, Department of Civil Engineering Technical University of Denmark, Denmark, Doctoral Thesis, 2012.

[5]. M. H. Zhang, O.E. Gjorv, Effect of silica fume on cement hydration in low porosity cement pastes, Cement and Concrete Research, 21 (1991) 800-808. https://doi.org/10.1016/0008$\underline{8846(91) 90175-\mathrm{H}}$

[6]. B. W. Langan, K. Weng, M.A. Ward, Effect of silica fume and fly ash on heat of hydration of Portland cement, Cement and Concrete Research, 32 (2002) 1045-1051. https://doi.org/10.1016/S0008-8846(02)00742-1

[7]. P. Chaunsali, S. Peethamparan, Evolution of strength, microstructure and mineralogical composition of a CKD-GGBFS binder, Cement and Concrete Research, 41 (2011) 197-208. https://doi.org/10.1016/j.cemconres.2010.11.010

[8]. C. L. Hwang, D.-H. Shen, The effects of blast furnace slag and fly ash on the hydration of portland cement, Cement and Concrete Research, 21 (1991) 410-425. https://doi.org/10.1016/0008$\underline{\text { 8846(91)90090-5 }}$

[9]. R. Siddique, Performance characteristics of high-volume Class F fly ash concrete, Cement and Concrete Research, 34 (2004) 487-493. https://doi.org/10.1016/j.cemconres.2003.09.002

[10].D. K. Panesar, Supplementary cementing materials, Woodhead Publishing Series in Civil and Structural Engineering, Elsevier Science \& Technology, 2019, pp 60-91.

[11].M.C. Chi., C. H. Wu., J. H. Chi., Effect of GGBFS on Compressive Strength and Durability of $\begin{array}{lllll}\text { Concrete, Advanced } & \text { Materials } & \text { 22-26. }\end{array}$ https://doi.org/10.4028/www.scientific.net/AMR.1145.22

[12].Z. Li, X. Zhao, T. He, S. Zhao, A study of high-performance slag-based composite admixtures, $\begin{array}{lllll}\text { Construction } & \text { Building } & \text { Material, } & 155 & \text { (2017) }\end{array}$ https://doi.org/10.1016/j.conbuildmat.2017.08.054

[13].R. Yu, P. Spiesz, H. J. H. Brouwers, Development of an eco-friendly ultra-high performance concrete (UHPC) with efficient cement and mineral admixtures uses, Cement Concrete Composite, 55 (2015) 383-394. https://doi.org/10.1016/j.cemconcomp.2014.09.024

[14].Q. Li, Q. Zhang, Experimental study on the compressive strength and shrinkage of concrete containing fly ash and ground granulated blast-furnace slag, International Federation for Structural Concrete, 20 (2019) 1551-1560. https://doi.org/10.1002/suco.201800295

[15].R. V. Sarathy, G. Dhinakaran, Strength and Durability Characteristics of GGBFS Based HPC, Asian Journal of Applied Sciences, 7 (2014) 224-231. https://doi.org/10.3923/ajaps.2014.224.231

[16].N.T.Sang, N. T. Khoa, Experimental Study on Effect of Ground Granulated Blast Furnace Slag of Strength and Durability of Sand Concrete, Innovation for Sustainable Infrastructure - CIGOS 2019, Lecture Notes in Civil Engineering 54, Springer Nature Singapore Pte Ltd, 2020, pp. 409-414. https://doi.org/10.1007/978-981-15-0802-8 63

[17].R. K. Pandey, A. Kumar, M. A. Khan, Effect of Ground Granulated Blast Furnace Slag as Partial Cement Replacement on Strength and Durability of Concrete: A Review, International Research Journal of Engineering and Technology (IRJET), 3 (2016) 1662-1666.

[18].V. M. Malhotra, P. K. Mehta, High performance, high-volume fly ash concrete, Supplementary cementing Materials for Sustainable Developpement Inc, Ottawa, Canada, 2012.

[19].P. Nath, P. K. Sarker, Effect of Fly Ash on the Durability Properties of High Strength Concrete, Procedia Engineering, 14 (2011) 1149-1156. https://doi.org/10.1016/j.proeng.2011.07.144

[20].B. W. Langan, Weng K., M.A. Ward, Effect of silica fume and fly ash on heat of hydration of 
Transport and Communications Science Journal, Vol. 71, Issue 7 (09/2020), 775-788

Portland cement, Cement and Concrete Research, 32 (2002) 1045-1051. https://doi.org/10.1016/S0008-8846(02)00742-1

[21].H. S. Chore, M. P. Joshi, Strength evaluation of concrete with fly ash and GGBFS as cement replacing materials, Advances in Concrete Construction, 3 (2015) 223-236. http://dx.doi.org/10.12989/acc.2015.3.3.223

[22].A. A. Phul, M. J. Memon, S. N. R. Shah, A. R. Sandhu, GGBS And Fly Ash Effects on Compressive Strength by Partial Replacement of Cement Concrete, Civil Engineering Journal, 5 (2019) 913-921. https://doi.org/10.28991/cej-2019-03091299

[23].A. R. Rosa, A. S. Miguel, A. M. Domingo, Granulated Blast-Furnace Slag and Coal Fly Ash Ternary Portland Cements Optimization, Sustainability, $12 \quad$ (2020) 5783. https://doi.org/10.3390/su12145783

[24].ASTM C618-19, Standard Specification for Coal Fly Ash and Raw or Calcined Natural Pozzolan for Use in Concrete, American Society for Testing and Materials, 2019.

[25].ASTM C138-19, Standard Test Method for Sieve Analysis of Fine and Coarse Aggregates, American Society for Testing and Materials, 2019.

[26].L. T. Ha, M. Muller, K. Siewert, H-M. Ludwig, The mix design for self-compacting high performance concrete containing various mineral admixtures, Materials and Design, 74 (2015) 51-62. https://doi.org/10.1016/j.matdes.2015.01.006

[27].J. E. Funk, D.R. Dinger, Predictive Process Control of Crowded Particulate Suspension, Applied to Ceramic Manufacturing, Kluwer Academic Press, 1994, 786 pp.

[28].ASTM C1202, Standard Test Method for Electrical Indication of Concrete's Ability to Resist ChlorideIon Penetration, American Society for Testing and Materials, 2019.

[29].ASTM C1138, Standard Test Method for Abrasion Resistance of Concrete, American Society for Testing and Materials, 2015.

[30].S. U. Khan, M. F. Nuruddin, T. Ayub, N. Shafiq, Effects of different mineral admixtures on the properties of fresh concrete, Scientific world Journal, 2014 (2014) 11. https://doi.org/10.1155/2014/986567

[31].O. M. Abdulkareem, Microstructure and Durability Properties of Environmentally Friendly UltraHigh Performance Concrete (UHPC), Thèse de Doctorat, Universite de Nantes, 2017.

[32].G. D. Moon, S. Oh, Y. C. Choi, Effects of the physicochemical properties of fly ash on the compressive strength of high-volume fly ash mortar, Constr Build Mater, 124 (2016) 1072-1080. https://doi.org/10.1016/j.conbuildmat.2016.08.148 